\title{
Copper Improves the Production of Laccase by the White- Rot Fungus Pleurotus pulmonarius in Solid State Fermentation
}

\author{
Giovana Kirst Tychanowicz ${ }^{1}$, Daniela F. de Souza ${ }^{1}$, Cristina G. M. Souza ${ }^{2}$, Marina Kimiko \\ Kadowaki $^{3}$ and Rosane Marina Peralta ${ }^{1 *}$ \\ ${ }^{1}$ Departamento de Bioquímica; rmperalta@uem.br; ${ }^{2}$ Departamento de Agronomia; Universidade Estadual de \\ Maringá; Maringá - PR - Brasil. ${ }^{3}$ Universidade Estadual de Cascavel; Cascavel - PR - Brasil
}

\begin{abstract}
Pleurotus pulmonarius (Fr) Quélet, produced laccase as the main ligninolytic enzyme when cultivated on solid-state cultures using corn cob as substrate. The addition of copper greatly increased the production of enzyme. The addition of $25.0 \mathrm{mM}$ CuSO4 increased the level of laccase from 270 to 1,420 U.L-1 and the fungus showed high resistance to copper under the conditions used in this work.
\end{abstract}

Key words: Copper, laccase, Pleurotus pulmonarius, phenoloxidase, solid state fermentation

\section{INTRODUCTION}

Laccases (benzenediol:oxygen oxidoreductases, EC 1.10.3.2) are glycosylated polyphenol oxidases that contain four copper ions per molecule. These enzymes catalyse the one-electron oxidation of a wide variety of organic and inorganic substrates, including mono-, di- and polyphenols, methoxyphenols, aromatic amines, and ascorbate, with concomitant four-electron reduction of oxygen to water (Leonowicz et al., 2001). Laccases are produced by the majority of white-rot fungi described to-date as well as by other types of fungi and plants, insects and some bacteria. Fungal laccases are believed to be involved in the degradation of lignin, the removal of potentially toxic phenols arising during lignin degradation, the fruit body development, pigment production and antimicrobial activity (Eggert, 1997).
Laccases have become important industrially relevant enzymes because of a number of diverse applications, e.g. for biocatalytic purposes such as delignification of lignocellulosics and crosslinking of polysaccharides, for bioremediation applications such as waste detoxification and textile dye transformation, for food technological uses, and for biosensor and analytical applications (Mayer and Staples, 2002).

In several organisms, laccases are constitutively produced in small amounts. However, their production can be considerably enhanced by a wide variety of substances, including aromatic or phenolic compounds, metal ions, alcohol, and detergents (Leonowicz et al., 2001). The increase in laccase activity by white-rot fungi in response to aromatic and phenolic substances such as ferulic acid, 2,5 xylidine, p-anisidine and veratryl alcohol is well-documented, the effect of metal ions, especially copper has only recently been

\footnotetext{
${ }^{*}$ Author for correspondence
} 
addressed. The effect of copper on laccase synthesis was studied in Trametes versicolor (Collins and Dobson, 1997), Pleurotus ostreatus (Palmieri et al., 2000) among several other whiterot fungi.

Recently, the capability of the white-rot fungus Pleurotus pulmonarius to produce high titres of laccase and efficiently to decolourise industrial dyes on submerged and solid-state systems was described (Zilly et al., 2002). The production of laccase was greatly affected by the presence of soluble phenolic compounds in the medium (Tychanowicz et al., 2004). The aim of this work was to study the effect of copper on the production of laccase by $P$. pulmonarius cultivated in solidstate cultures.

\section{MATERIALS AND METHODS}

\section{Organism and culture conditions}

Pleurotus pulmonarius CCB-19 was obtained from the Culture Collection of the São Paulo Botany Institute. It was cultured on potato dextrose agar slants for 2 weeks at $28^{\circ} \mathrm{C}$. When the slant was fully covered with the mycelia, mycelial plugs measuring $10 \mathrm{~mm}$ in diameter were made and used as inoculum for solid state cultures. For production of enzymes on solid- state system, four mycelial plugs were transferred to $250 \mathrm{ml}$ Erlenmeyer flasks containing $5 \mathrm{~g}$ of corn cob (approximate size $3 \times 3 \times 2 \mathrm{~mm}^{3}$ ) enriched with $0.15 \mathrm{~g}$ of glucose and $0.014 \mathrm{~g}$ ammonium tartrate. Approximately $15 \mathrm{~mL}$ of mineral solution (Herpöel et al., 2000) was used to adjust the moisture content to $75 \%$. This medium was designated in this work as basal medium. The basal medium was supplemented with different amounts of $\mathrm{CuSO}_{4} .5 \mathrm{H}_{2} \mathrm{O}, \quad \mathrm{MnSO}_{4} \cdot \mathrm{H}_{2} \mathrm{O}$, $\mathrm{ZnSO}_{4} .7 \mathrm{H}_{2} \mathrm{O}, \mathrm{AgNO}_{3}, \mathrm{CdSO}_{4} \cdot 8 \mathrm{H}_{2} \mathrm{O}, \mathrm{HgCl}_{2}$ and $\mathrm{MgCl}_{2} \cdot 6 \mathrm{H}_{2} \mathrm{O}$ ranging from 0 to $15.0 \mathrm{mM}$. Dry weight of the substrate and moisture content were determined gravimetrically, after drying samples at $105^{\circ} \mathrm{C}$. Incubation was carried out at $30^{\circ} \mathrm{C}$. At periodic intervals, $50 \mathrm{ml}$ of cold water was added to the cultures and the mixtures were shaken for 1 $\mathrm{h}$ at $4^{\circ} \mathrm{C}$. The mixtures were filtered, and the filtrates were used as enzymatic extract. Results were expressed as the mean of at least three different cultures.

\section{Enzyme assays}

Laccase activity was performed spectrophotometrically at $525 \mathrm{~nm}$ in a reaction medium containing $0.5 \mathrm{mM}$ syringaldazine $\left(\varepsilon_{525}=65 \mathrm{mM}^{-1} \mathrm{~cm}^{-1}\right)$ in $0.1 \mathrm{M}$ phosphate buffer (Leonowicz and Grzywnowicz, 1981). The aryl alcohol oxidase (AAO) activity was estimated by the oxidation of $5 \mathrm{mM}$ veratryl alcohol $(3,4$ dimethoxybenzyl alcohol) to veratraldehyde in 0.1 $\mathrm{M}$ sodium phosphate buffer, $\mathrm{pH} 6.0\left(\varepsilon_{310}=9.30\right.$ $\mathrm{mM}^{-1} \mathrm{~cm}^{-1}$ ) (Muñoz et al., 1997). The manganese peroxidase $(\mathrm{MnP})$ activity was assayed by the oxidation of $1 \mathrm{mM} \mathrm{MnSO}_{4}$ in $0.05 \mathrm{M}$ sodium

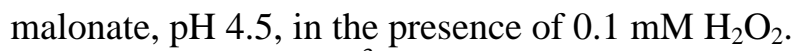
Manganic ions, $\mathrm{Mn}^{+3}$, form a complex with malonate, which absorbs at $270 \mathrm{~nm}\left(\varepsilon_{270}=11.59\right.$ $\mathrm{mM}^{-1} \mathrm{~cm}^{-1}$ ) (Wariishi et al., 1992). The lignin peroxidase activity was determined as the oxidation rote of $4 \mathrm{mM}$ veratryl alcohol to veratraldehyde in $0.1 \mathrm{M}$ tartrate buffer $\mathrm{pH} 3.0$ in the presence of $0.2 \mathrm{mM}$ of $\mathrm{H}_{2} \mathrm{O}_{2}$ (Tien and Kirk, 1983). The enzymatic activity was expressed as international units (U) defined as the amount of enzyme required to produce $1 \mu \mathrm{mol}$ product. $\mathrm{min}^{-1}$ and expressed as U.L $\mathrm{L}^{-1}$. The differences in laccase production $(\mathrm{P}<0.01)$ among the treatments tested were assessed using one-way ANOVA with Tukey's honestly significant difference contrasts.

Determination of residual glucose and ammonium nitrogen

Residual glucose was determined by using the glucose oxidase kit from Labtest ${ }^{\circledR}$ (Brazil). Residual $\mathrm{NH}_{4}{ }^{+}-\mathrm{N}$ was determined by the salicylate-hypochlorite method (Forster, 1995).

\section{Chemicals}

The enzymatic substrates, syringaldazine and veratryl alcohol were obtained from Sigma Chemical Corp. (St. Louis, Mo). All other reagents were of analytical grade.

\section{RESULTS AND DISCUSSION}

Effect of copper and other metal ions on laccase production by $P$. pulmonarius on solid state cultures

To study the effect of metallic ions on the growth and on laccase formation, the basal medium (glucose-ammonium tartrate-corn cob powder) was supplemented with $\mathrm{Cu}^{2+}, \mathrm{Ag}^{+}, \mathrm{Cd}^{2+}, \mathrm{Cu}^{2+}$, 
$\mathrm{Hg}^{2+}, \mathrm{Mn}^{2+}$ and $\mathrm{Zn}^{2+}$ (Fig. 1). $\mathrm{Ag}^{+}, \mathrm{Cd}^{2+}$ and $\mathrm{Hg}^{2+}$ were highly toxic for the organism and very low growth was observed in these cultures. When 15.0 $\mathrm{mM}$ of $\mathrm{Cu}^{2+}$ or $\mathrm{Mn}^{2+}$ were added to the cultures, a stimulatory effect in the laccase activity, more evident to copper, was observed. These results are in agreement with the data of literature where copper has been reported as a strong laccase inducer in white-rot fungi (Collins and Dobson 1997). $\mathrm{Mg}^{2+}$ did not produce any effect in both growth and laccase production. No visual alteration on the growth and on the levels of laccase activity was observed by the addition of $4.0 \mathrm{mM}$ of $\mathrm{Cu}^{2+}$. In the cultures supplemented with $15.0 \mathrm{mM}$ of $\mathrm{Cu}^{2+}$, an evident visual inhibition of growth was observed (data not shown).

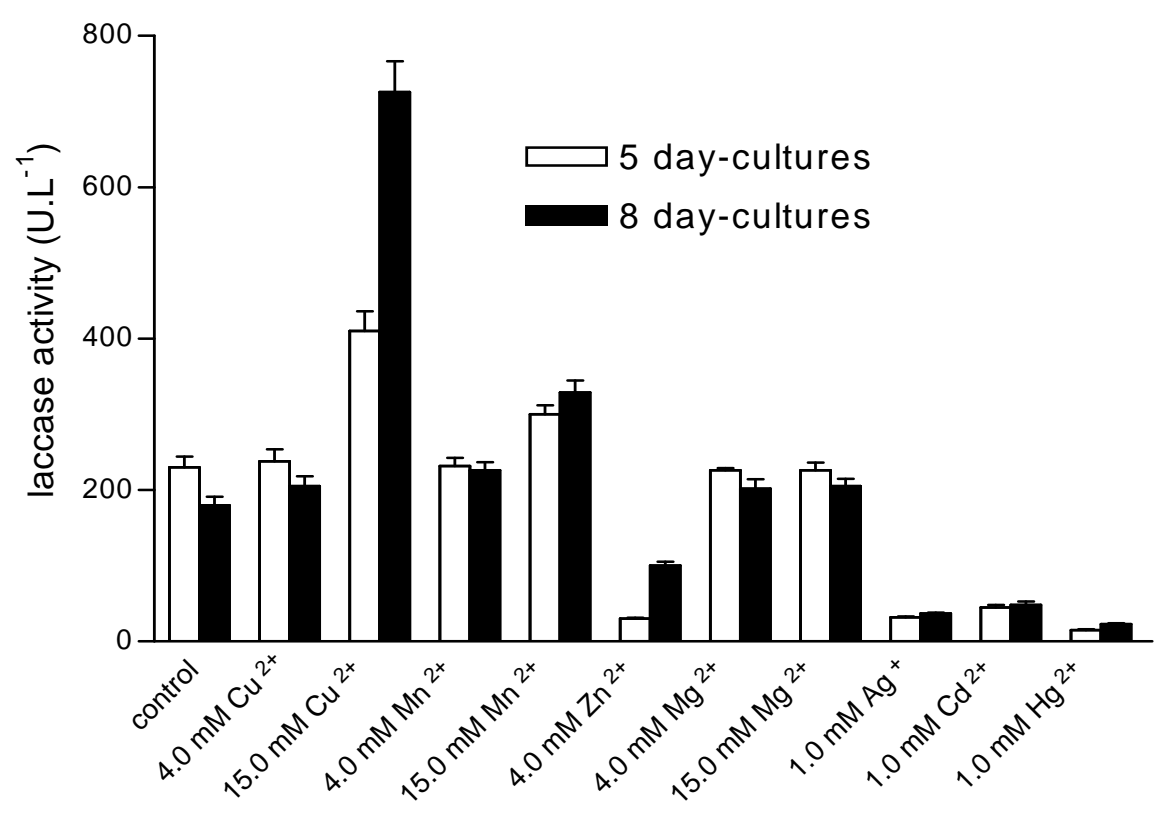

Figure 1 - Effect of metallic ions in the production of laccase by P. pulmonarius in solid-state fermentation.

The time course of solid-state cultures supplemented with different amounts of copper is shown in Fig. 2. When copper was added to the cultures up to $10.0 \mathrm{mM}$, no inhibition in the consumption of substrates glucose and ammonium, and no alteration in the levels of laccase activity were observed in the cultures. In the culture where copper at $10.0-25.0 \mathrm{mM}$ was present, the decrease in the glucose and ammonium consumption by the fungus suggested inhibition of growth (Fig. 2B-2C). However, in these cultures, laccase activity increased up to 8fold when compared with the levels of enzyme obtained in the control cultures $\left(270\right.$ U.L ${ }^{-1}$ in the basal medium) to 1,420 U.L ${ }^{-1}$ in the medium supplemented with $25.0 \mathrm{mM} \mathrm{CuSO} 4$ ). No growth was observed when more than $40 \mathrm{mM}$ of copper was added in the cultures, even after 20 days of cultivation. Very low AAO, Mn peroxidase and lignin peroxidase activities were detected in all cultures, supplemented or not with copper. Copper is an essential micro-nutrient for most living organisms, and copper requirements by microorganisms are usually satisfied by very low concentrations of the metal, in order of $1-10 \mu \mathrm{M}$. However, copper present in higher concentration is extremely toxic to microbial cells (Labbé and Thiele 1997), although some copper-tolerant fungi had already been described (De Groot and Woodward 1999). The results suggested that in solid-state cultures, $P$. pulmonarius presented high resistance to copper.

In the ascomycete Podospora anserina, in which laccase mRNA, amongst others, increased in response to copper and aromatic compounds, it was postulated that laccase acts as a defense mechanism against oxidative stress (FernandezLarrea and Stahl, 1996). This protective function was partly attributed to the chelation of copper ions during synthesis of the laccase enzyme. It is 
well known that copper can cause oxidative damage of proteins by the induction of oxidative stress associated with the production of reactive oxygen species like hydroxyl or superoxide radicals (Stohs and Bagchi 1995). In Pleurotus ostreatus cultures, the presence of copper decreased the activity of an extracellular protease
(Palmieri et al., 2001). This might explain the positive of copper on enzyme stabilization in the crude extracts. Metal responsive elements (MRE) were identified in the promoters of $P$. ostreatus laccase genes poxc and poxa $1 \mathrm{~b}$ (Baldrian, 2003). These MERs interact with copper-responsive transcription factors.
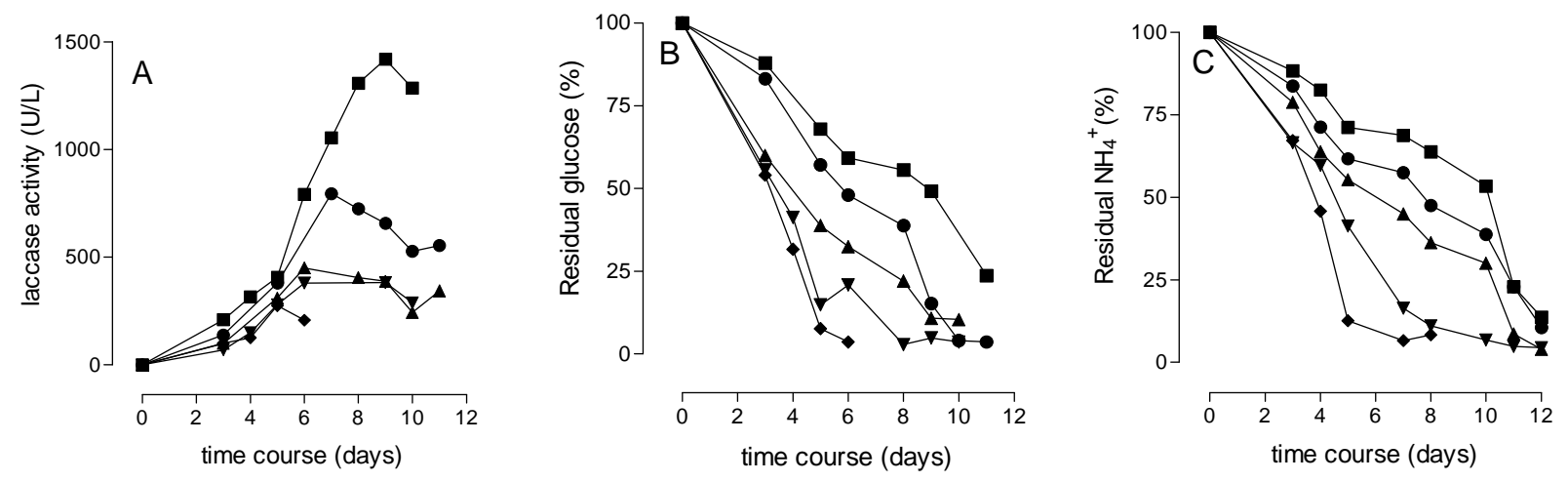

Figure 2 - Effect of $\mathrm{CuSO}_{4}$ on laccase production and glucose and ammonium consumption by $P$. pulmonarius. The organism was grown on a glucose-ammonium tartrate-corn cob solid system and several amounts of $\mathrm{CuSO}_{4}$ was added: $(\bullet)$ control culture; $(\boldsymbol{\nabla})$ plus $10.0 \mathrm{mM} \mathrm{CuSO}_{4} ;(\boldsymbol{\Delta})$ plus $15.0 \mathrm{mM} \mathrm{CuSO}_{4} ;(\bullet)$ plus $20.0 \mathrm{mM} \mathrm{CuSO}_{4} ;(\mathbf{\bullet})$ plus $25.0 \mathrm{mM} \mathrm{CuSO}_{4}$.
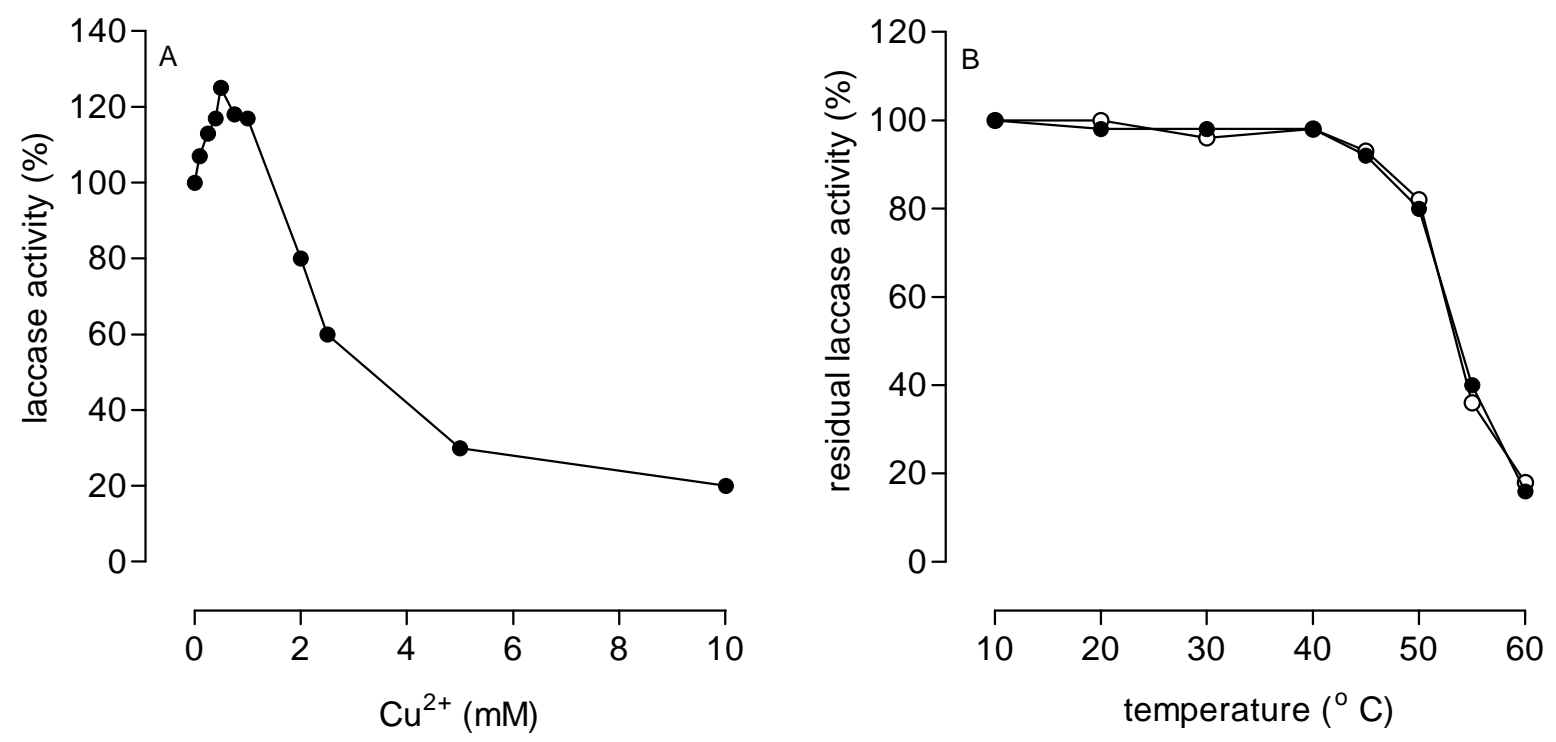

Figure 3 - Effect of copper on the activity (A) and stability (B) of crude $P$. pulmonarius laccase. In A: the laccase activity was assayed using 6 day-culture filtrate without supplementation of copper. In B: The enzyme was incubated during $1 \mathrm{~h}$ at several temperatures in the absence $(\bullet)$ or presence of $1 \mathrm{mM} \mathrm{CuSO}_{4}(\circ)$ 


\section{Effect of copper on in vitro laccase activity}

The activity of laccase in vitro was determined under different copper concentrations (Fig. 3). At lowest copper concentrations, the enzyme was slightly activated. At $1 \mathrm{mM} \mathrm{CuSO}$, the enzyme was $20 \%$ more active than in the absence of copper. However, highest concentrations of copper inhibited the enzyme (Fig. 3A). The presence of 1 $\mathrm{mM}$ copper did not increase the stability of the enzyme when it was maintained $1 \mathrm{~h}$ at several temperatures (Fig. 3B). These data suggested that the increase of laccase activity in $P$. pulmonarius cultures after copper addition was due to increased laccase production and not by activation and/or stabilisation of the enzyme in the extracellular environmental, considering that $1 \mathrm{mM}$ of copper slightly activated the enzyme and had no effect in the stabilisation of enzyme and the activity of enzyme was inhibited by copper at concentrations higher than $1 \mathrm{mM}$. Recently, it has been shown that Pleurotus ostreatus laccase was greatly activated by the presence of copper in the reaction medium (Baldrian and Gabriel, 2002).

Several studies showed the regulation of the synthesis of several different laccase isoforms by copper occurs at the level of gene transcription (Collins and Dobson, 1997, Palmieri et al., 2000). The supplementation of $P$. ostreatus cultures with copper increased the production of all isoenzymes of laccase produced by the fungus (Baldrian, 2003).

\section{CONCLUSION}

Until now most studies of effect of copper on the production of laccase have been carried out using liquid cultures. To our knowledge, this is the first report that describes the effect of copper on the production of laccase by a white-rot fungus cultivated in solid-state system, a condition under which the fungus grew closer as found in the nature. The addition of copper in solid-state cultures of $P$. pulmonarius efficiently stimulated laccase formation by the fungus. The reason why copper effectively stimulates $P$. pulmonarius laccase synthesis is at present not clear and new experiments are necessary to understand the induction process. However, the use of cupper enriched solid-state cultures can be an attractive way to obtain high titres of laccase wich could be useful in several industrial applications.

\section{ACKNOWLEDGEMENTS}

This work was supported by grants from Conselho Nacional de Desenvolvimento Científico e Tecnológico (CNPq), Fundação Araucária and Universidade Estadual de Maringá. R. M. Peralta is research fellow of CNPq. G. K. Tychanowicz is recipient of a CAPES Fellowship. We thank M. A. F. Costa and A. Chaves for technical assistance.

\section{RESUMO}

Pleurotus pulmonarius (Fr) Quélet, um basidiomiceto causador da podridão branca da madeira produz lacase como principal enzima ligninolítica quando cultivado em meio em estado sólido utilizando sabugo de milho como substrato. $\mathrm{O}$ íon cobre tem grande efeito na produção da enzima. Os melhores resultados foram obtidos pela adição de $25.0 \mathrm{mM}$ de $\mathrm{CuSO}_{4}$ que causou uma elevação dos níveis enzimáticos de 270 U.L ${ }^{-1}$ para 1.420 U.L $\mathrm{L}^{-1} \mathrm{O}$ fungo mostrou uma alta resistência ao íon cobre nas condições de cultivo utilizadas neste trabalho.

\section{REFERENCES}

Baldrian, B. and Gabriel, J. (2002), Copper and cadmium increase laccase activity in Pleurotus ostreatus. FEMS Microbiol. Lett., 206, 69-74.

Baldrian, P. (2003), Interactions of heavy metals with white-rot fungi. Enz. Microb. Technol., 32, 78-91.

Collins, P. J. and Dobson, A. D. W. (1997), Regulation of laccase gene transcription in Trametes versicolor. Appl. Environ. Microbiol., 63, 3444-345.

De Groot, R. C. and Woodward, B. (1999), Using copper-tolerant fungi to biodegrade wood treated with copper-based preservatives. Int. Biodet. Biodegrad., 44, 17-27.

Eggert, C. (1997), Laccase is responsible for antimicrobial activity of Picnoporus cinnabarinus. Microbiol. Res., 152, 315-318.

Fernandez-Larrea, J. and Stahl, U. (1996), Isolation and characterization of a laccase gene of Podospora anserina. Mol Gen Genet, 149, 65-70.

Forster, J. C. (1995), Soil nitrogen. In: Alef, K and Nannipieri, P. (Eds.). Methods in applied soil microbiology and biochemistry. London: Academic Press. pp. 79-87.

Herpoel, I.; Moukha, S.; Lesage-Meessen, L.; Sigoillot J. C. and Asther, M. (2000), Selection of Picnoporus cinnabarinus for laccase production. FEMS Microbiol. Lett., 183, 301-306. 
Labbé, S. and Thiele, D. J. (1997), Pipes and wiring: the regulation of copper uptake and distribution in yeast. Trends Microbiol., 7, 500-505.

Leonowicz, A. and Grzywnowicz, K. (1981), Quantitative estimation of laccase forms in some white-rot fungi using syringaldazine as a substrate. Enz. Microbiol. Technol., 3, 55-58.

Leonowicz, A.; Cho, N. S.; Luterek, J.; Wilkolazka, A.; Wojtas-Wasilewska, M.; Matuszewska, A.; Hofrichter, M. and Wesenberg, D. (2001), Fungal laccase: properties and activity on lignin. J. Bas. Microbiol., 41, 185-227.

Mayer, A. F. and Staples, R. C. (2002), Laccase: new functions for an old enzyme. Phytochemistry, 60, 551-565.

Munoz, C.; Guillen, F.; Martinez, A.T. and Martinez, M. J. (1997), Induction and characterization of laccase in the ligninolytic fungus Pleurotus eryngii. Curr. Microbiol., 34, 1-5.

Palmieri, G.; Bianco, C.; Cennamo, G.; Giardina, P.; Marino, G.; Monti, M. and Sannia, G. (2001), Purification, characterization, and functional role of a novel extracellular protease from Pleurotus ostreatus. Appl. Environ. Microbiol., 67, 2754-2759.

Palmieri, G.; Giardina, P.; Bianco, C.; Fontanella, B. and Sannia, G. (2000), Copper induction of laccase isoenzymes in the ligninolytic fungus Pleurotus ostreatus. Appl. Environ. Microbiol., 66, 920-924.

Stohs, S. J. and Bagchi, D. (1995), Oxidative mechanisms in the toxicity of metal ions. Free Rad. Biol. Med., 18, 321-336.
Tien, M. and Kirk, T. K. (1983), Lignin degrading enzyme from Phanerochaete chrysosporium: purification, characterization and catalytic properties of unique $\mathrm{H}_{2} \mathrm{O}_{2}$-requiring oxygenase. Proc. Natl. Acad. Sci. USA, 81, 2280-2284.

Tychanowicz, G. K.; Zilly, A.; Souza, C. G. M. and Peralta, R. M. (2004), Decolourisation of industrial dyes by solid state cultures of Pleurotus pulmonarius. Proc. Biochem., 39, 855-859.

Wariishi, H.; Valli, K.; Gold, M. H. (1992), Manganese (II) oxidation by manganese peroxidase from the basidiomycete Phanerochaete chrysosporium. J. Biol. Chem., 267, 23688-23695.

Zilly, A.; Souza, C. G. M.; Barbosa-Tessmann, I. P. and Peralta, R. M. (2002), Decolorization of industrial dyes by a Brazilian strain of Pleurotus pulmonarius producing laccase as the sole phenol-oxidizing enzyme. Folia Microbiol., 47, 315-319.

Received: March 04, 2005; Revised: December 08, 2005; Accepted: July 14, 2006. 